Bangladesh J. Plant Taxon. 23(2): 133-142, 2016 (December)

(C) 2016 Bangladesh Association of Plant Taxonomists

\title{
INDIAN CHEILANTHOID FERN - A NUMERICAL TAXONOMIC APPROACH
}

\author{
Kakali SEn ${ }^{1}$ and Radhanath Mukhopadhyay ${ }^{2}$ \\ Department of Botany, University of Kalyani, Pin-741235, Kalyani, Nadia, West Bengal, India
}

Keywords: Cheilanthoid fern; Cluster analysis; Micromorphology; Numerical taxonomy.

\begin{abstract}
Twenty one species belonging to five genera (viz. Aleuritopteris Fēe, Cheilanthes Sw., Doryopteris J. Sm., Notholaena R. Brown, Pellaea Link.) of the Indian cheilanthoid ferns were studied to develop the new data set of micromorphological details viz. epidermal cells, stomatal morphotypes, venation pattern and spore ultrastructre. Cluster analysis was performed by using the two- state of multiple characters that separate the genus Aleuritopteris from Cheilanthes at the Eucladian distance of 5.1, though completely linked with other closely related genera, viz. Doryopteris, Notholaena and Pellaea. The taxonomic conundrum lies within these genera was resolved with numerical taxonomic study.
\end{abstract}

\section{Introduction}

Cheilanthoid ferns form an evolutionary group with the strong tendency to be confined in the three large continental/archipelago land areas of America, Africa and Asia-Malaysia. The centre of diversity of the genera is in America and especially in Mexico, where about 100 species form the richest xeric fern flora in the world (Tryon and Tryon, 1982). In India, the distribution range is very wide from the altitudinal variations of plains $(100 \mathrm{~m})$ to the slopes and small pockets of Himalaya (3000 m.), Nilgiri and Palni hills of South (Nayar, 1962; Dixit, 1984; Pande and Pande, 2003; Sen and Mukhopadhyay, 2011). The group is characterized by the sporangia on the abaxial side of the lamina, covered or not by a marginal pseudoindusium without veins, sporangia approximate in sori or soral lines, stipes at the base with one vascular bundle, sometimes with two, lamina farinose or efarinose, stems with scales, rarely with hairs, base chromosome no. $n=29$ or 30 (Nayar, 1962; Tryon and Tryon, 1990).

Cheilanthes and Aleuritopteris are old and phylogenetically problematical genera (genus 'arduum' of Fee) generally included among the gymnogrammeoid or placed in the Cheilanthaceae (family nov.) by Nayar (1962) or Pteridaceae (Tryon and Tryon, 1982; Smith et al., 2006). Difficulties in identifying discrete generic boundaries among the cheilanthoids have long been attributed to convergent evolution driven by adaptation to arid environment (Tryon and Tryon, 1973). The workers frequently echo the comment on that "there is an obvious need for the development of new data which will give a better insight into the evolutionary lines within the group" (Tryon and Tryon, 1973). And the workers of molecular systematics also inferred for the genus Cheilanthes that "it needs redefinition" (Smith et al., 2006). Among cheilanthoid ferns the depositions of farina are used widely to delineate section Aleuritopteris (presence of farina) from section-Cheilanthes (absence of farina) though it breaks at the wider geographical scales (Nayar, 1962; Khullar, 1994). But the potential adaptive significance of the farina has made it a trait of evolutionary interest.

\footnotetext{
${ }^{1}$ Corresponding author. Email: itskakali@gmail.com

${ }^{2}$ CAS, Department of Botany, University of Burdwan, Pin-713104, Burdwan, West Bengal, India. Present Address: 8/3, Dinabandhu Mukherjee Lane, Shibpur, Howrah, Pin-711102, West Bengal, India.
} 
To redefine Aleuritopteris and Cheilanthes and also to regenerate new character sets to resolve the ambiguity of their generic status our present study is attempted to focus mainly the micromorphological characters. On the basis of the multiple dataset of two character- state, taxa were clustered to establish the interrelationships that exist among them.

\section{Materials and Methods}

Detail list of specimens studied are mentioned in the Table 1. For cluster analysis of the 21 taxa studied as many as 9-two state characters (i.e. characters which exist in two alternative forms or states i.e. either present or absent for generic segregation (Table 2); for $12 \mathrm{spp}$. of Aleuritopteris, 43-two state characters (Table 3) and for 6 spp. of Cheilanthes 42-two state characters (Table 4), were taken into account to prepare the data matrix. Responses of each taxon to each of these characters were coded in a data matrix as ' 1 ' and ' 0 ' respectively for two alternative states i.e. presence or absence. The data thus recorded were further utilized in finding the overall similarities or rather the distance between taxa and putting them in clusters using the concept of 'Euclidean Distance' for measuring distance and 'Complete Linkage' for amalgamation or linkage. Statistical analysis was performed using Statistica-6 (Sneath and Sokal, 1973).

Images of the standard character-sets used for the analysis were taken in Leica QWIN 80 microscope and Scanning Electron Microscope, Model No. Japan Hitachi 530.

\section{Results and Discussion}

The morphometric study was performed to delineate the taxa of the cheilanthoid fern at the generic and infrageneric level. For numerical taxonomic study the suitable characters used at the generic level are mentioned in the Table 2. For clustering at the infrageneric level used characters are mentioned in Table 3 (Genus Aleuritopteris) and Table 4 (Genus Cheilanthes) respectively. Figure 4(A-I) and Fig. 5(A-K) shows the contrasting character states as stated in Tables 2-4. Previously, all the works performed by various workers (Nayar, 1962; Tryon and Tryon, 1982; Khullar, 1994) have given much importance to the farina character, which is a potential synapomorphy and have some evolutionary interest (Sigel et al., 2011). But, the wholesome approach of character is giving a better clue of separation at both the generic and infrageneric level (Sen, 2014). The works at the molecular phylogeny also found some dispute for this group when the regional basis of works was performed (Gastony and Rollo, 1995, 1998; Zhang, 2007).

On the basis of phenetic study of the 5 genera, close relation or affinity with each other was noticed. The genus Aleuritopteris Fee and Notholaena R. Brown form a group and Doryopteris J. Sm and Pellaea Link. form another group; these two groups are allied with each other and form a broad group with Cheilanthes Sw. One important ambiguity which persisted so long regarding the generic segregation of Aleuritopteris from Cheilanthes gets some clear clue from this phenetic study in that they are quite apart from each other in phenogram but are linked. The characters as mentioned by Fraser-Jenkins and Dulawat (2009) to distinguish the genus Cheilanthes from Aleuritopteris, are narrow stipe scale and narrow leaf segment, which are very vague as is evident from our numerical data enlisted (Table 2).

To categorise the infrageneric taxa, phenetic study resolves some ambiguity. Placement of $C$. subvillosa Hook. under the genus Cheilanthes is also corroborated by our study as the taxon possesses similarity in generic characters with Cheilanthes. The placement of its synonym Aleuritopteris subvillosa (Hook.) Ching under the genus Aleuritopteris by Fraser-Jenkins and Dulawat (2009) is however not in conformity with the present study. 
Table 1. List of taxa studied is mentioned here. For each taxon only one specimen is enlisted.

\begin{tabular}{|c|c|c|}
\hline Sl.No. & Name of the taxa & Herbarium details \\
\hline 1. & $\begin{array}{l}\text { Aleuritopteris albomarginata } \\
\text { (Clarke) Ching }\end{array}$ & $\begin{array}{l}\text { 52761, 02.05.1975,R.D.Dixit,Takdah -Athmal Reserve, } \\
\text { Darjeeling, West Bengal, } \\
\text { 9125(CAL); }\end{array}$ \\
\hline 2. & A. anceps (Blanford) Panigrahi & $\begin{array}{l}\text { 59343,27.03.1985,B. Ghosh and S.R. Ghosh, } \\
\text { K.T. Road,950 m. Manipur, CAL }\end{array}$ \\
\hline 3. & A. argentea (Gmel.)Fee & Zwa-Kabru, 6958 (CAL). \\
\hline 4. & A. bicolor (Roxb.) Fraser-Jenkins & KS - 183, 12.10.2012; Kakali Sen, Almora, \\
\hline 5. & A. bullosa (Kunze) Ching & 1878, Zy. King, Nilgiri Hills,(CAL); \\
\hline 6. & A. chrysophylla (Hook.) Ching & 08.08.1892, G.A. Gammie,Lachung, Sikkim , 7136 (CAL) \\
\hline 7. & A. doniana S.K.Wu & $\begin{array}{l}\text { KS -146, 06.10.2010, Kakali Sen } \\
\text { Dello Kalimpong(BURD) }\end{array}$ \\
\hline 8. & A. formosana (Hayata)Tagawa & KS -149,06.10.2010,Kakali Sen,Dello, Kalimpong(BURD) \\
\hline 9. & A.grisea (Blanf) Panigr. & $\begin{array}{l}\text { 15205, Feb. 1972, Panigrahi,Bilaspur, M.P. } \\
\text { (CAL). }\end{array}$ \\
\hline 10. & A. rufa (Don) Ching & $\begin{array}{l}\text { KS -204,09.10.2012, Kakali Sen, Samla Tal, Tanakpur, } \\
\text { Uttarakhand(BURD) }\end{array}$ \\
\hline 11. & A. subargentea Ching ex $\mathrm{Sk}$. Wu & July, 1904, J. Walton, Sangpo valley, 6952 (CAL) \\
\hline 12. & $\begin{array}{l}\text { A. subdimorpha (C.B.Clarke and } \\
\text { Baker) Fraser-Jenk. }\end{array}$ & KS -157,08.10.2010, Kakali Sen, Bhusuk, Gangtok(BURD) \\
\hline 13. & $\begin{array}{l}\text { Cheilanthes acrostica (Balbis) } \\
\text { Tod }\end{array}$ & $\begin{array}{l}\text { 02.01.1986, B.P.Uniyal Archi, Jammu and Kashmir, 80379, } \\
\text { (CAL); }\end{array}$ \\
\hline 14. & C. belangeri (Bory) C.Chr. & $\begin{array}{l}\text { 21.10.1952, Rev. B. Godfrey, 7088, N.Lushai Hills, Assam } \\
\text { (CAL); }\end{array}$ \\
\hline 15. & C. keralansis Nair and Ghosh. & $\begin{array}{l}\text { 49442, 29.07.1977, A.N. Henry, Kanyakumari, } \\
\text { Keeriparai(CAL) }\end{array}$ \\
\hline 16. & C. mysorensis Wall. ex. Hook. & $\begin{array}{l}\text { 09.11.2001, P. Amrutalakshmi, Nellore, Andhrapradesh, } \\
25119 \text { (CAL); }\end{array}$ \\
\hline 17. & C. subvillosa Hook. & 466, Tamilnadu, 9048 (CAL) \\
\hline 18. & C. tenuifolia (Burm.) Sw. & $\begin{array}{l}\text { 8614, 24.09.81, M.K. Mama and U.P. Samaddar, Netarhat, } \\
\text { Palamau Dist., Bihar, } 936 \text { (CAL); }\end{array}$ \\
\hline 19. & $\begin{array}{l}\text { Doryopteris concolor (Langsd. } \\
\text { and Fisch.) Kuhn }\end{array}$ & 04.11.1996, Sanchita Gangopadhyay, Kodaikanal (BURD); \\
\hline $\begin{array}{l}20 . \\
21 .\end{array}$ & $\begin{array}{l}\text { Notholaena marantae (L.)Desv. } \\
\text { Pellaea bovinii Hook. }\end{array}$ & $\begin{array}{l}\text { 3673, 18.09.1984, J.F.Duthie (BURD); } \\
\text { 7671, December, 1910, A. Meeblod, 6000 }{ }^{\mathrm{ft}} \text {, Devicolani, S. } \\
\text { India, } 13487 \text { (CAL). }\end{array}$ \\
\hline
\end{tabular}

Table 2. Characters taken for Generic segregation of cheilanthoid ferns by cluster analysis.

\begin{tabular}{lcc}
\hline Characters taken & \multicolumn{2}{c}{ Character State } \\
\cline { 2 - 3 } & absent & $(1)$ \\
\hline 1. Indusium & absent & present \\
2. Farina & coriaceous & present \\
3. Leaf texture & sessile & membranous or herbaceous \\
4. Pinna & absent & stalked \\
5. Vascular commissure & absent & present \\
6. Indument on leaf surface & pripinnate leaf present & always \\
7. Pinna dissection & dissected than 1-pinnate \\
8. Pinna margin & present & entire \\
9. Non-perinate spores & & absent \\
\hline
\end{tabular}


Table 3. Characters taken for cluster analysis of Aleuritopteris spp.(infrageneric level).

\begin{tabular}{|c|c|c|}
\hline \multirow[t]{2}{*}{ Characters taken } & \multicolumn{2}{|c|}{ Character State } \\
\hline & $(0)$ & $(1)$ \\
\hline 1. $\quad$ Stipe scale & base & throughout \\
\hline 2. Rachis scale & absent & present \\
\hline 3. Scales & present in costae \& costule & absent \\
\hline 4. Rhizome scale & non-clathrate & clathrate \\
\hline 5. Rhizome scale & concolorous & bicolorous \\
\hline 6. Rhizome scale & non-glandular & glandular \\
\hline 7. Stipe scale & non-clathrate & clathrate \\
\hline 8. Stipe scale & concolorous & bicolorous \\
\hline 9. Farina & white & golden Yellow \\
\hline 10. Indusial & margin entire & with fimbriated projections \\
\hline 11. Stomatal type & polocytic & polo- and other type \\
\hline 12. Position of stomata & hypostomatic & amphistomatic \\
\hline 13. Pinnae & opposite & alternate \\
\hline 14. Pinnae & sessile & stalked \\
\hline 15. Lamina shape & lanceolate & boat shaped \\
\hline 16. Lamina & glabrous & indument present (except farina gland) \\
\hline 17. Petiole color & $\tan$ & black \\
\hline 18. Venation & open dichotomous & not \\
\hline 19. Vein ending & dilated & Not dilated \\
\hline 20. Dichotomization pattern & $\leq 3$ & $>3$ \\
\hline 21. Vein goes & upto the margin & not \\
\hline 22. Position of sorus & sorus at vein tip & some distance away from tip \\
\hline 23. Epidermal cell surface & convex & concave \\
\hline 24. Epidermal cellwall width & $\geq 5 \mu \mathrm{m}$ & $<5 \mu \mathrm{m}$ \\
\hline 25. Guard cell length & $\geq 30 \mu \mathrm{m}$ & $<30 \mu \mathrm{m}$ \\
\hline 26. Rhizome scale length & $\geq 4 \mathrm{~mm}$ & $<4 \mathrm{~mm}$ \\
\hline 27. Rhizome scale width & $\geq 0.5$ & $<0.5$ \\
\hline 28. Stipe scale length & $\geq 4$ & $<4$ \\
\hline 29. Stipe scale width & $\geq 0.5$ & $<0.5$ \\
\hline 30. Stipe/rachis length ratio & $\geq 1$ & $<1$ \\
\hline 31. Blade width & $\geq 5 \mathrm{~cm}$ & $<5 \mathrm{~cm}$ \\
\hline $\begin{array}{l}\text { 32. Length/width ratio basalmost } \\
\text { pinna of basal segments }\end{array}$ & $\geq 4$ & $<4$ \\
\hline $\begin{array}{l}\text { 33. Length/width ratio median pinna } \\
\text { of basal segments }\end{array}$ & $\geq 3$ & $<3$ \\
\hline $\begin{array}{l}\text { 34. Length ratio of } \\
\text { acroscopic/basiscopic segments of } \\
\text { basal pinna }\end{array}$ & $\geq 0.5$ & $<0.5$ \\
\hline $\begin{array}{l}\text { 35. Width ratio of } \\
\text { acroscopic/basiscopic segments of } \\
\text { basal pinna }\end{array}$ & $\geq 0.6$ & $<0.6$ \\
\hline 36. Spore Dia $(\mathrm{P})$ & $\geq 30 \mu \mathrm{m}$ & $<30 \mu \mathrm{m}$ \\
\hline 37. Spore Dia (E) & $\geq 50 \mu \mathrm{m}$ & $<50 \mu \mathrm{m}$ \\
\hline 38. Exine thickness & $\geq 2 \mu \mathrm{m}$ & $<2 \mu \mathrm{m}$ \\
\hline 39. Laesural (L)longest arm & $\geq 25 \mu \mathrm{m}$ & $<25 \mu \mathrm{m}$ \\
\hline 40. Crassimarginate/tenuimarginate & Crassimarginate & tenuimarginate \\
\hline 41. Perine & not cristate & cristate \\
\hline 42. Tapetal depositions & absent & present \\
\hline 43. Perisporic strands & present & absent \\
\hline
\end{tabular}


Table 4. Characters taken for cluster analysis of Cheilanthes spp.(infrageneric level).

\begin{tabular}{|c|c|c|}
\hline \multirow[t]{2}{*}{ Characters taken } & \multicolumn{2}{|c|}{ Character state } \\
\hline & $(0)$ & (1) \\
\hline 1. Stipe scale & base & throughout \\
\hline 2. Rachis scale & absent & present \\
\hline 3. Scales & present in costae \& costule & absent \\
\hline 4. Rhizome scale & non-clathrate & clathrate \\
\hline 5. Rhizome scale & non-glandular & glandular \\
\hline 6. Stipe scale & non-clathrate & clathrate \\
\hline 7. Stipe scale & concolorous & bicolorous \\
\hline 8. Farina & white & golden Yellow \\
\hline 9. Indusial margin & entire & with fimbriated projections \\
\hline 10. Stomatal type & polocytic & polo and other type \\
\hline 11. Position of stomata & hypostomatic & amphistomatic \\
\hline 12. Pinnae & opposite & alternate \\
\hline 13. Pinnae & sessile & stalked \\
\hline 14. Lamina shape & lanceolate & boat shaped \\
\hline 15. Lamina & glabrous & $\begin{array}{l}\text { indument present (except } \\
\text { farina gland) }\end{array}$ \\
\hline 16. Petiole color & $\tan$ & black \\
\hline 17. Venation & open dichotomous & not \\
\hline 18. Vein ending & dilated & Not dilated \\
\hline 19. Dichotomization pattern & $\leq 3$ & $>3$ \\
\hline 20. Vein goes & upto the margin & not \\
\hline 21. Position of sorus & sorus at vein tip & some distance away from tip \\
\hline 22. Epidermal cell surface & convex & concave \\
\hline 23. Epidermal cell wall width & $\geq 1 \mu \mathrm{m}$ & $<1 \mu \mathrm{m}$ \\
\hline 24. Guard cell length & $\geq 40 \mu \mathrm{m}$ & $<40 \mu \mathrm{m}$ \\
\hline 25. Rhizome scale length & $\geq 4 \mathrm{~mm}$ & $<4 \mathrm{~mm}$ \\
\hline 26. Rhizome scale width & $\geq 0.5$ & $<0.5$ \\
\hline 27. Stipe scale length & $\geq 4$ & $<4$ \\
\hline 28. Stipe scale width & $\geq 0.5$ & $<0.5$ \\
\hline 29. Stipe/rachis length ratio & $\geq 1$ & $<1$ \\
\hline 30. Blade width & $\geq 5 \mathrm{~cm}$ & $<5 \mathrm{~cm}$ \\
\hline $\begin{array}{l}\text { 31. Length/width ratio basalmost } \\
\text { pinna of basal segments }\end{array}$ & $\geq 4$ & $<4$ \\
\hline $\begin{array}{l}\text { 32. Length/width ratio median } \\
\text { pinna of basal segments }\end{array}$ & $\geq 3$ & $<3$ \\
\hline $\begin{array}{l}\text { 33. Length ratio of } \\
\text { acroscopic/basiscopic segments } \\
\text { of basal pinna }\end{array}$ & $\geq 0.5$ & $<0.5$ \\
\hline $\begin{array}{l}\text { 34. Width ratio of acroscopic / } \\
\text { basiscopic segments of basal } \\
\text { pinna }\end{array}$ & $\geq 0.6$ & $<0.6$ \\
\hline 35. Spore $\operatorname{Dia}(\mathrm{P})$ & $\geq 30 \mu \mathrm{m}$ & $<30 \mu \mathrm{m}$ \\
\hline 36. Spore $\operatorname{Dia}(\mathrm{E})$ & $\geq 50 \mu \mathrm{m}$ & $<50 \mu \mathrm{m}$ \\
\hline 37. Exine thickness & $\geq 2 \mu \mathrm{m}$ & $<2 \mu \mathrm{m}$ \\
\hline 38. Laesural (L)longest arm & $\geq 25 \mu \mathrm{m}$ & $<25 \mu \mathrm{m}$ \\
\hline 39. Crassimarginate/tenuimarginate & crassimarginate & tenuimarginate \\
\hline 40. Perine & absent & present \\
\hline 41. Tapetal depositions & absent & Present \\
\hline 42. Perisporic strands & present & absent \\
\hline
\end{tabular}


The placement of the genera Hemionitis L., Parahemionitis Panigrahi and Pityrograma Link. with cheilanthoid group of ferns (Fraser-Jenkins and Dulawat, 2009) must not be supported as their taxonomic positions were clarified earlier by Smith et al. (2006) on the basis of morphology as well as molecular taxonomy in other subfamilies Hemionitidae and Taenitidae respectively.

\section{Phenetic study}

\section{Cluster analysis at generic level}

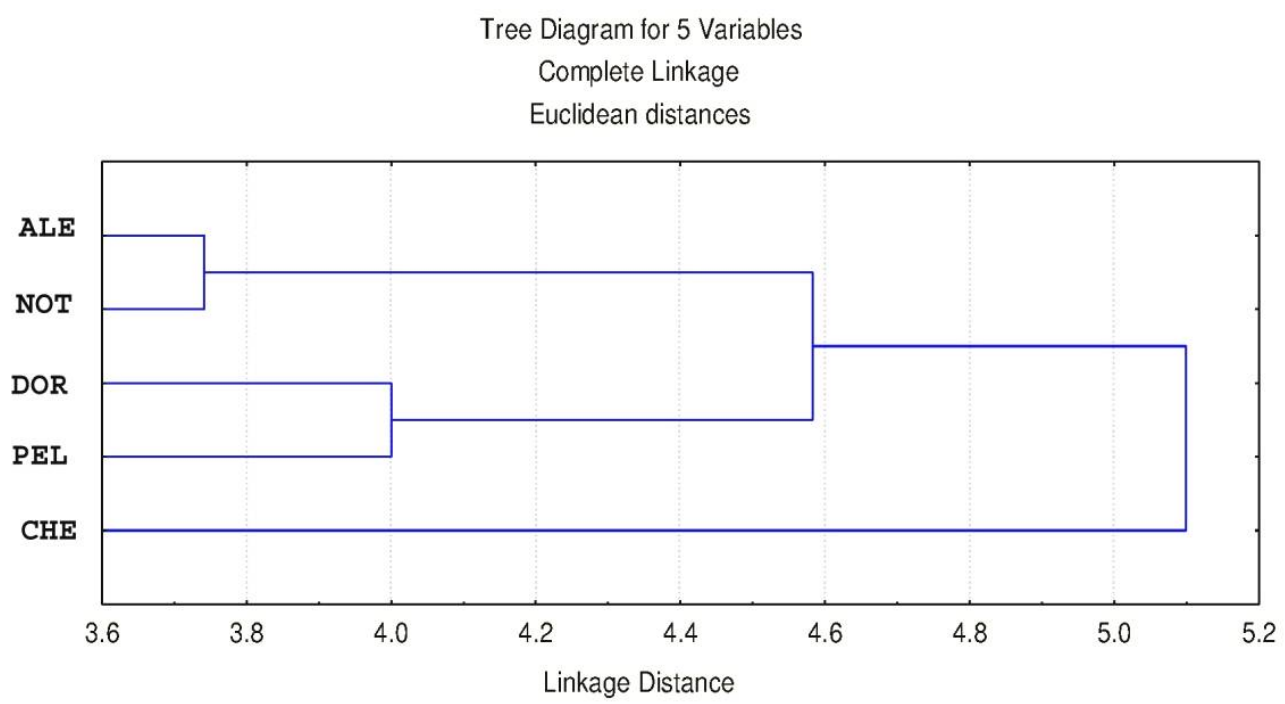

Fig. 1. Shows the relationship of cheilanthoid ferns at generic level (Abbrev.ALE-Aleuritopteris; CHECheilanthes, DOR-Doryopteris, NOT-Notholaena, PEL-Pellaea).

Aleuritopteris (ALE) and Notholaena (NOT) have the nearest relation as is revealed from complete linkage at the Euclidean Distance of c.3.7. There is another closely related cluster formed by Doryopteris (DOR) and Pellaea (PEL) at the linkage distance of 4.0 which in its turn show a relationship with the first cluster at the distance of c.4.6 to form a larger cluster which shows a natural affinity with Cheilanthes (CHE) more or less at the Euclidean Distance of 5.1. All the OTUs under study, although individually distinct, are thus moderately related because of their overall similarity at the ED of 5.1

\section{Cluster analysis at infrageneric level}

Cluster analysis of Aleuritopteris spp.

A. argentea (AAR) and A.subargentea (ASR) have the nearest relation as is revealed from complete linkage at the Euclidean Distance of c.2.8. At the level of the linkage Distance of 3.5 as many as 8 clusters can be recognized of which 4 are with solitary OTUs (Operational taxonomic Unit), viz. A. rufa (ARU), A. chrysophylla (ACH), A. formosana (AFO), A. subdimorpha (ASD). However, at the Linkage Distance of 4.5 three large clusters are recognizable, viz. AAL, AAN, ARU; AAR, ASR, ACH, ABI, ADO, AFO; ABU, AGR, ASD. The relatedness of the last two clusters mentioned is greater than with the first cluster which is clearly expressed at the distance of 4.7. However all the OTUs under study, although individually distinct, are linked ultimately at the Ed of 4.8 because of their moderate overall similarity. 
Tree Diagram for 12 Variables

Complete Linkage

Euclidean distances

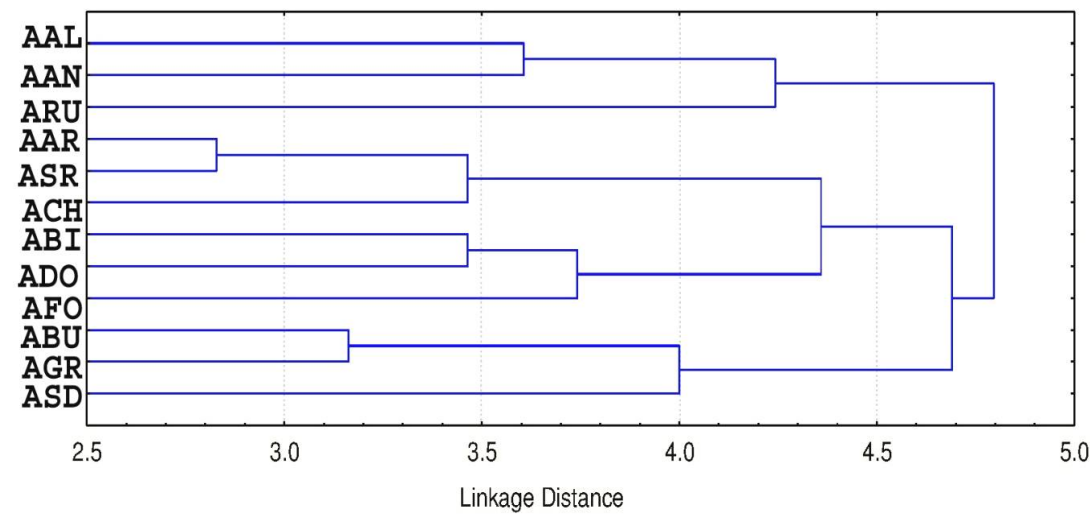

Fig. 2. Shows the infrageneric relationship of Aleuritopteris [Abbrev.: AAL- Aleuritopteris albomarginata (Clarke) Ching; AAN -A. anceps (Blanf.)Panigr. AAR- A. argentea (Gmel)Fee; ABI- A. bicolor (Roxb.) FraserJenkins; ABU- A. bullosa (kze)Ching; ACH- A. chrysophylla (Hook) Ching; ADO- A. doniana S.K.Wu; AFO- A. formosana (Hay.) Tagawa; AGR- A. grisea (Blanf.)Panigr; ARU- A. rufa (D.Don)Ching; ASR- A. subargentea Ching ex Wu; ASD- A. subdimorpha (Clarke et Bak.)Fras.-Jenk.].

Cluster analysis of Cheilanthes spp.

Cheilanthes acrostica (Balbis)Tod (CAC) and C. mysorensis Wall ex.Hook. (CMY) have the nearest relation as is revealed from complete linkage at the Euclidean Distance of c.2.8. These OTUs in their turn show a relationship with $C$. belangeri (Bory) C.Chr. (CBE) at the distance of 4.0. At the same distance are linked C.keralensis Nair and Ghosh (CKE) and C. subvillosa Hook. (CSU). However, this cluster shows affinity with C.tenuifolia (CTE) more or less at the Euclidean Distance of 4.5. All the OTUs under study, although individually distinct, are related because of their overall similarity getting linked slightly above the Ed of 5.0.

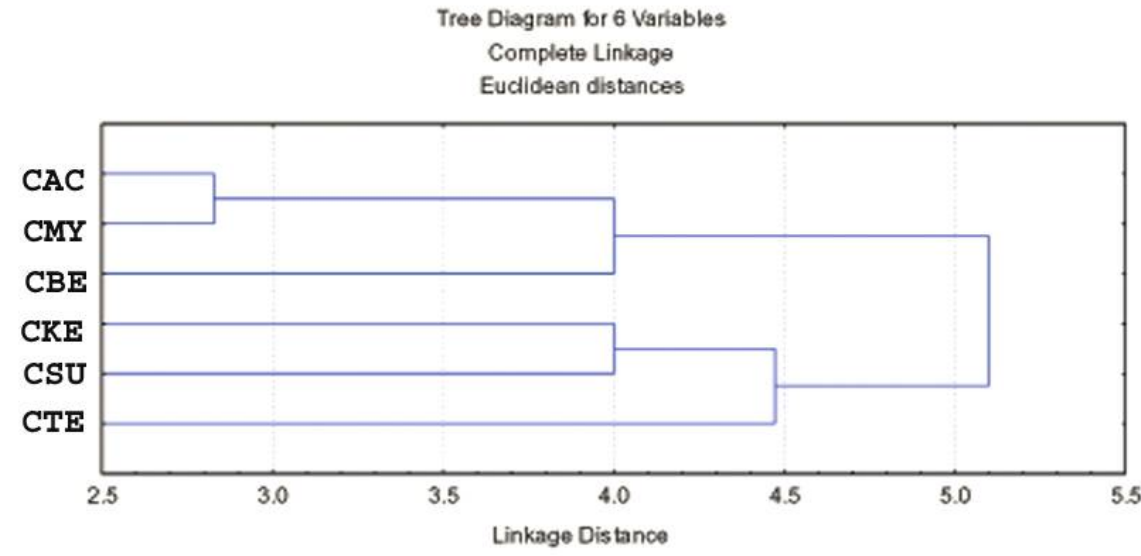

Fig. 3. Shows the infrageneric relationship of Cheilanthes (Abbrev.: CAC-Cheilanthes acrostica, CBE- $C$. belangeri, CKE- C. keralensis, CMY- C. mysorensis, CSU- C. subvillosa, CTE- C. tenuifolia). 


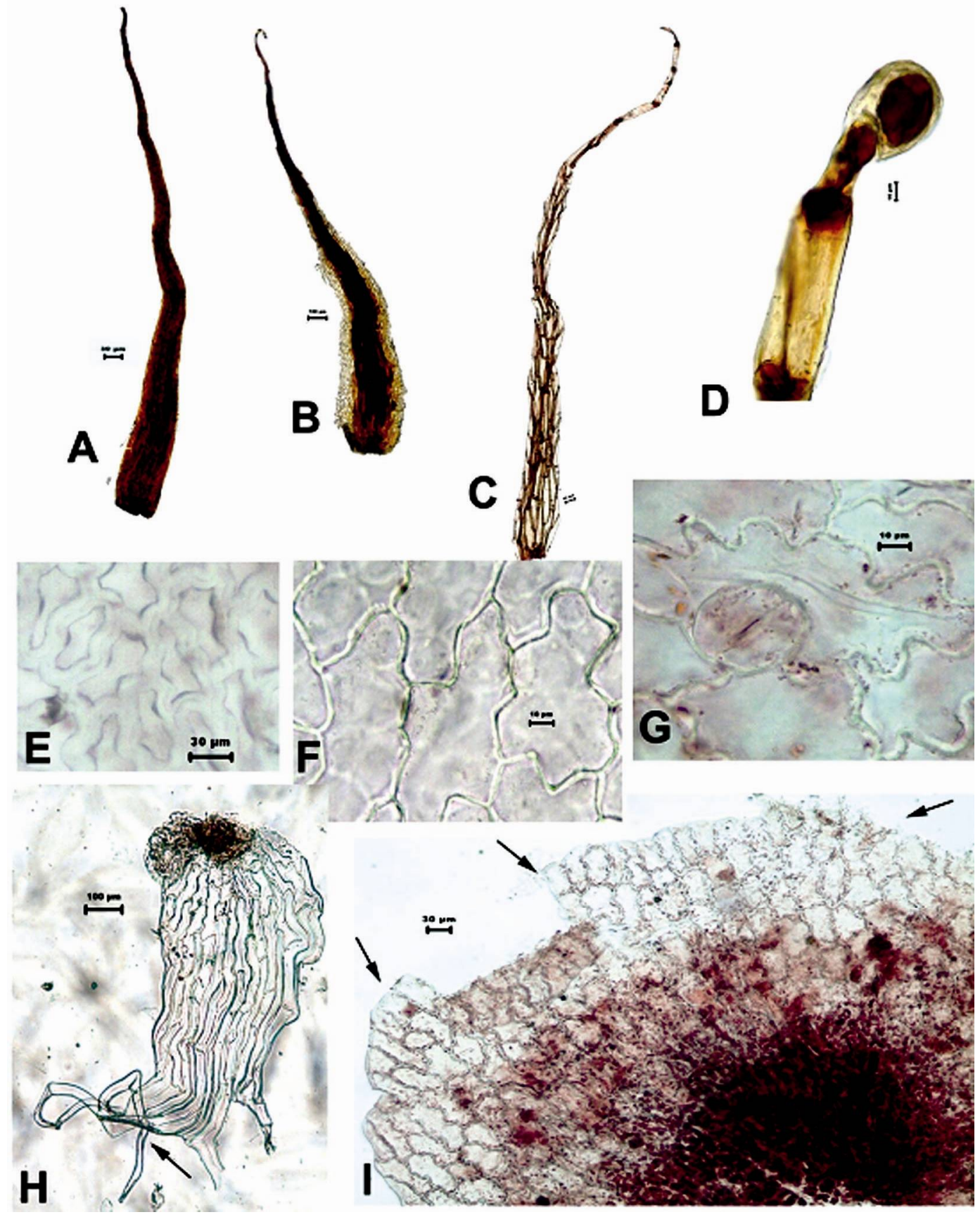

Fig. 4. LM images of different characters used in cluster analysis. A) concolorous scale of Aleuritopteris subdimorpha B)bicolorous scale of A. formosana C) clathrate non-glandular scale of $A$. rufa D) Glandular scale tip-Cheilanthes mysorensis E) epidermal cell-A. chrysophylla F) epidermal cell- $C$. keralensis $\mathrm{G}$ ) polocytic stomata-C.acrostica $\mathrm{H}$ ) fimbriated indusial margin-A.rufa (arrowhead shows the fimbriated margin) I) entire indusial margin-A. chrysophylla (arrowhead shows the entire margin). 

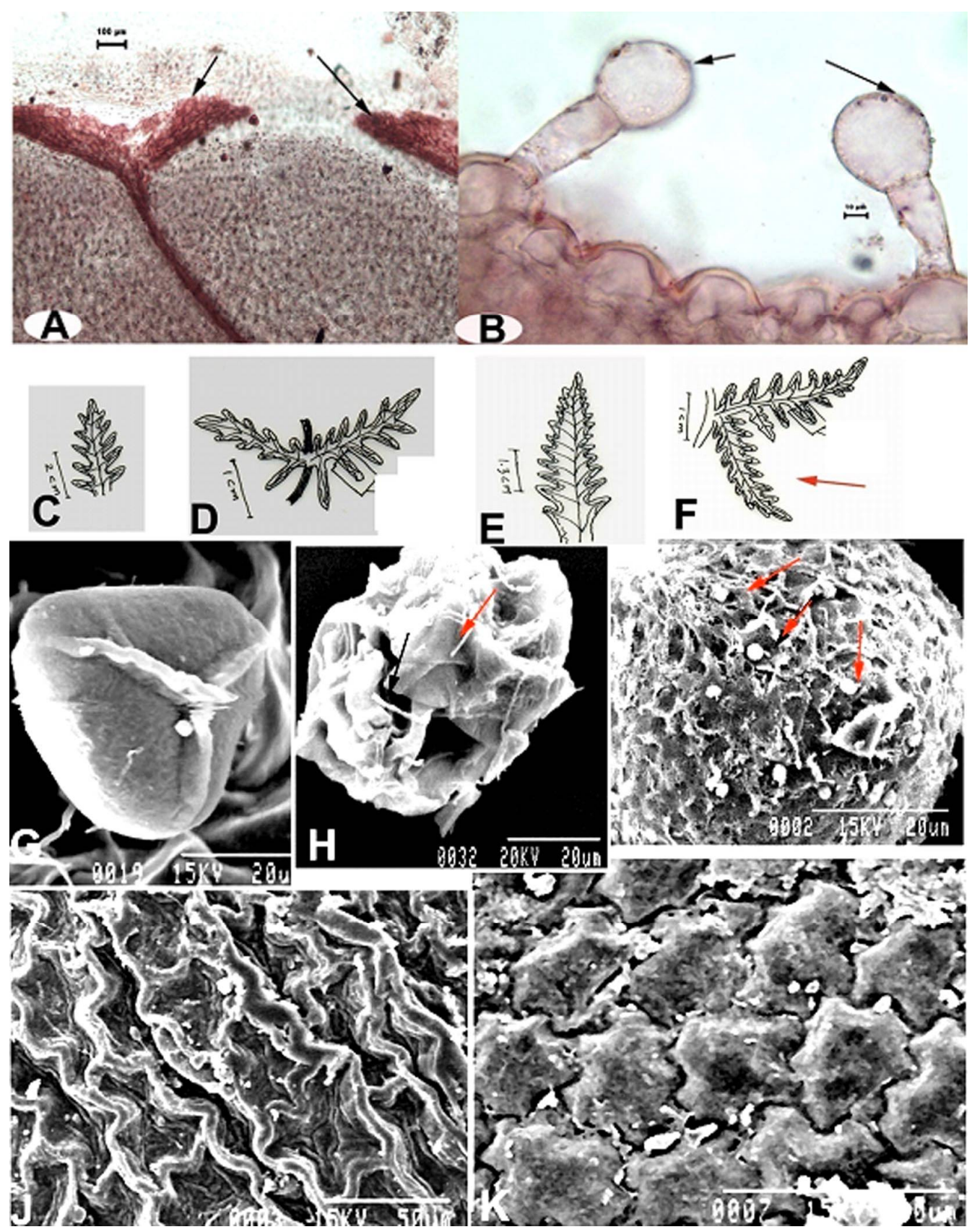

Fig. 5. LM (A-B), Free hand drawing (C-F) \& SEM (G-K) images of characters used in cluster analysis. A) Commissural vein of Doryopteris concolor (arrowhead shows the marginal joining of veins)B) leaf gland of Cheilanthes keralensis C-D)ultimate \& basal segment of leaf - Aleuritopteris albomarginata E-F) ultimate \& basal segment of leaf- A.bicolor G) non-perinous spore-C. tenuifolia $\mathrm{H}$ ) perisporic strands-Pellaea falcata I)tapetal deposits-A.chrysophylla(arrowhead shows the globular deposits) J) convex epidermal surface(adaxial)-A. bullosa $\mathrm{K}$ ) concave epidermal surface(adaxial)-A.formosana. 
The dendrogram based on phenetic study clearly revealed the interrelationships of five Indian cheilanthoid genera of arid region. Despite of their homoplasy of characters (Tryon and Tryon, 1973; Sen and Mukhopadhyay, 2014; Sen, 2014) they can be separated, though linked, clearly by using a multiple sets of characters. Present study is the first report describing the correlation between the cheilanthoid ferns of India at generic and infrageneric level and also establishes the generic segregation of Aleuritopteris and Cheilanthes by doing numerical taxonomic study.

\section{Acknowledgements}

Prof. Ambarish Mukherjee, Department of Botany, University of Burdwan, West Bengal is acknowledged for his kind care and help to perform this work. Also Mr. Kaushik Sarkar, Technical Assistant, \& Dr. Srikanta Chakrabarty, USIC, University of Burdwan is acknowledged for taking the LM \& SEM images. Two anonymous reviewers are also acknowledged here for their critical comment to improve the manuscript.

\section{References}

Dixit, R.D. 1984. A census of the Indian Pteridphytes. Flora India Series IV- Bot. Surv. India. pp.1-177.

Fraser-Jenkins, C.R. and Dulawat, C.S. 2009. A summary of Indian cheilanthoid ferns and the discovery of Negripteris (Pteridaceae), an afro-arabian fern genus new to India. Fern Gaz. 18(5): 216-229.

Gastony, G.J. and Rollo, D.R.1995.Phylogeny and generic circumscriptions of cheilanthoid ferns (Pteridaceae:Cheilanthoideae) inferred from rbcL nucleotide sequences. Amer. Fern. J. 85: 341-360.

Gastony, G.J. and Rollo, D.R. 1998. Cheilanthoid ferns (Pteridaceae: Cheilanthoideae) in the Southwestern United States and Adjacent Mexico - a molecular phylogenetic reassessment of generic lines. Aliso 17:131-144.

Khullar, S.P. 1994.An illustrated fern flora of west Himalaya (Vol. I). International Book Distributors, Bishen Singh and Mahendra Pal singh, Dehra Dun, Indi, pp.1- 506.

Nayar, B.K. 1962. Ferns of India, no. VI, Cheilanthes. Nat. Bot. Gard. Lucknow, pp.1-35.

Pande, H.C. and Pande P.C., 2003. An illustrated fern flora of the Kumaon Himalaya. Vol.I, Bishen Singh Mahendra pal Singh, Dehra Dun, pp.1-372

Sen, K. and Mukhopadhyay R. 2011. LM and SEM Studies on Stomatal Morphotypes, Epidermal Characteristics and Spore Morphology of Some Indian Species of Cheilanthes Sw. Bioresearch Bulletin 5: 304-310.

Sen, K. and Mukhopadhyay, R. 2014, New report of vessel elements in Aleuritopteris and Cheilanthes, Taiwania 59(3): 231-239.

Sen, K. 2014, Ph.D. Thesis. "Studies in the morpho-anatomy \& taxonomy of some Indian cheilanthoid ferns. Department of Botany, University of Burdwan.

Sigel, E. M., Windham, M. D., Huiet, L., Yatskievych, G.and Pryer, K. M. 2011. Species Relationships and Farina Evolution in the Cheilanthoid Fern Genus Argyrochosma (Pteridaceae). Syst. Bot. 36(3): 554564.

Smith, A. R., Pryer, K.M., Schuettpelz, E., Korall, P., Schneider H. and Wolf, P.G. 2006. A classification of extant ferns. Taxon, 55: 705-731.

Sneath, P.H.A. and Sokal, R.R.1973: Numerical Taxonomy. W.H. Freeman, San Francisco, pp.1-573.

Tryon, A.F., and Lugardon, B., 1990. Spores of the Pteridophyta: surface, wall structure, and diversity based on electron microscope studies. Springer-Verlag, New York, pp.1-415.

Tryon, R.M. and Tryon, A.F. 1973. Geography, spores and evolutionary relations in the cheilanthoid ferns. In: Jermy,A.C.,Crabbe, J.A. and Thomas, B.A.(Eds.), "The Phylogeny and Classifications of the Ferns". Academic Press, London. pp. 145-153.

Tryon, R.M., and. Tryon. A.F 1982. Ferns and allied plants, with special reference to tropical America. Springer-Verlag, New York, pp.1-857.

Zhang, G., Zhang, X., Chen, Z., Liu, H., and Yang, W. 2007. First insights in the phylogeny of Asian cheilanthoid Ferns based on sequences of two chloroplast markers. Taxon 56(2): 369-378. 